\title{
THE LEGISLATIVE RESOLUTION OF THE RULEMAKING VERSUS ADJUDICATION PROBLEM IN AGENCY LAWMAKING
}

\author{
WILLIAM T. MAYTON*
}

\section{Introduction: Of Crocodile Tears}

Over the past several years there has been considerable debate as to whether federal agencies should develop law and policy by adjudication, a traditional "lawmaking" forum, or by rulemaking, a forum unique to agencies. The consensus is that, in both theory and practice, rulemaking is the superior forum. It permits broad-based participation that benefits the affected public and educates the agency, its procedures expedite policy development, and its requirement that standards be codified and published promotes clarity and uniform application of law. ${ }^{1}$ Thus, the rulemaking process has been acclaimed as one of the "greatest inventions of modern government," and the agencies' failure to utilize it has been deplored.2 But these laments may be, in the words of Judge Friendly, no more than "crocodile tears."

The commonplace opinion is that the agencies can, in their discretion, formulate law and pohicy, which is to say rules, by adjudication as well as rulemaking. ${ }^{4}$ Consequently, the courts, in their task of holding

* Associate Professor of Law, Emory University School of Law; B.S. 1963, University of South Carolina; J.D. 1972, Columbia University.

THE FOLLOWING CITATIONS WILL BE USED IN THIS ARTICLE:

S. REP. No. 752, 79th Coug., Ist Sess. (1945) [hereinafter cited as S. REP. No. 752];

Senate Comm. on the Judiclary, Administrative Procedure Act, Legislative HisTORY, S. Doc. No. 248, 79th Cong., 2d Sess. (1946) [hereinafter cited as APA LEG. HISTORY];

attorney General's Committee on administrative Procedure, Final Report, S. Doc. No. 8, 77th Cong., 1st Sess. (1941) [hereinafter cited as ATT'Y GeNERAI's REP.].

1. See generally Bernstein, The NLRB's Adjudication-Rule Making Dilemma Under the Administrative Procedure Act, 79 YALE L.J. 571 (1970); Elman, Rulemaking Procedures in the FTC's Enforcement of the Merger Law, 78 HARv. L. Rev. 385 (1964); Peck, The Atrophied Rule-Making Powers of the National Labor Relations Board, 70 YALE L.J. 729 (1961); Shapiro, The Choice of Rulemaking or Adjudication in the Development of Administrative Policy, 78 HARV. L. REv. 921 (1965); Wright, The Courts and the Rulemaking Process: The Limits of Judicial Review, 59 CoRNELL L. REV. 375, 376 (1974).

2. $1 \mathrm{~K}$. Davis, Administrative Law Treatise $\$ 6: 1$ (2d ed. 1978).

3. H. \& F. Binch Co. v. NLRB, 456 F.2d 357, 365 (2d Cir. 1972).

4. "It has become well established that agencies which possess both adjudication and rulemaking powers covering the same subject matter generally may choose whether to proceed by means of adjudication or of rule making in resolving particular policy problems confronting 
the agencies to appointed procedures, have stopped short of an effective rulemaking requirement; rather, they have allowed the agencies the discretion to develop rules by adjudication. The errors in this are at least twofold. First, it is contrary to the mandate of Congress that, in a broad sphere, rulemaking procedures are an exclusive process for the development of rules. 5 Second, the present "abuse of discretion" standard $^{6}$ for determining the propriety of ruleinaking vis-a-vis adjudication precludes analysis of whether the agency action in question is in fact a lawmaking activity that should be subject to the rulemaking process. $^{\text {? }}$

This Article in Part II examines the legislative requirement of a mandatory rulemaking process; Part III discusses the Supreme Court's obfuscation of this mandate. Finally, Part IV analyzes the sphere of agency action that recent case law identifies as subject to the ruleinaking process. The purpose of this Article is not to rehash pohicy arguments as to the relative merits of rulemaking and adjudication in agency developinent of law and pohcy. Rather, the aim is to clarify the controlling legislative resolution of this problein.

\section{The Congressional Mandate of Rulemaking}

Congress often enacts regulatory legislation with broad substantive provisions: enactınents, for example, making illegal "unfair labor practices." 8 Congress then delegates to an agency the task of defining precisely the range of proscribed conduct. At the agency level these statutes might be impleinented in an ad hoc fashion by a series of adjudications applying the broad statute to the specific conduct of specific parties. From these adjudications, standards more precisely defining the statutory mandate may be developed. Creating these standards through adjudication is a lawmaking activity on the part of the agency-a kind of lawmaking that gains a ready acceptance when one

them." Fuchs, Development and Diversification in Administrative Rule Making, 72 Nw. U.L. REv. 83, 89 (1977). See also cases cited at note 89 infra.

5. See notes 20-61 infra and accompanying text.

6. See text accompanying notes 135-37 infra.

7. While there has been considerable "policy" debate as to the merits of rulemaking vis-avis adjudication, little attention has been directed to the controlling mandate of Congress. For example, one article comparing the rulemaking and adjudicatory processes addresses this issue in a footnote, stating that "[i]t has been suggested that an agency may under some circumstances be violatimg the rulemaking requirements of the APA when it formulates rules im adjudication." Shapiro, supra note 1 , at $927 \mathrm{n.21}$. The suggested solution was that "an agency is subject to those requirements [rulemaking] only when it is acting as a legislature would, not when it is acting as a court." Id. This approach, it seems, only begs the larger question: when should an agency act like a legislature and when should it act like a court?

8. National Labor Relations Act, 29 U.S.C. $\S \S 157,158(a)(1)$ (1976). 
considers that this is how the courts make law.

Congress, however, cognizant of the broad lawmaking authority that it delegates to agencies, sought to supplant the adjudication model of lawmaking with a superior process. In section 4 of the Administrative Procedure Act (APA), ${ }^{9}$ Congress circumscribed agency lawmaking activities by imposing a procedure unique to agencies: it required that rules be formulated pursuant to "notice and comment" procedures and that these rules be codified and published. ${ }^{10}$ That Congress linked its delegation of lawmaking authority to this rulemaking process has not gone unobserved. As stated by the Court of Appeals for the First Circuit, "the premise supporting congressional and judicial approval of such vague delegations is that the agency, through the rulemaking and administrative process, will gradually fill in areas of uncertainty with specific rules."11

The rulemaking process that Congress established in its plenary authority can be described as a legislative-like hearing, ${ }^{12}$ with the minimal procedural requirenients of notice to the interested public of a proposed rule and an opportunity to comment on the substance of that rule. "Notice," including the time and place of the proceeding and the subject matter of the proposed rule, must be pubhished in the Federal Register. ${ }^{13}$ "Interested persons" may then participate by submitting

9. 5 U.S.C. $§ 553$ (1976).

10. 5 U.S.C. $\S 553($ b) -(d) (1976).

11. South Terminal Corp. v. EPA, 504 F.2d 646, 670 (Ist Cir. 1974). See also Morton v. Ruiz, 415 U.S. 199 (1973):

The power of an administrative agency to administer a congressionally created and funded program necessarily requires the formulation of policy and the making of rules to fill any gap left, inplicitly or exphicitly, by Congress. . . . This agency power to make rules that affcct substantial individual rights and obligations carries with it the responsibility . . . to einploy procedures that conform to the law.

Id. at 231-32; Aiken v. Obledo, 442 F. Supp. 628, 651 (E.D. Cal. 1977) (when Congress has only "roughed-im its program," rulemaking is essential).

12. Rulemaking is a legislative-like activity appropriate to Congress and its delegatees-the agencies. According to an authoritative study of the administrative process, "the whole field of rule-Inaking. . . is outside the constitutional competence of the courts, for rules do not determine the rights of specific litigants but, like statutes, are addressed to people geuerally." ATT'Y GENERAL'S REP. 12.

The courts do hold the agencies to observing proper procedures in rulemaking. However, procedures established by Congress are controlling, because due process does not apply to procedures incidental to the formulation of rules. See Bi-Metallic Investment Co. v. Colorado, 239 U.S. 441 (1915).

13. These "notice and comment" procedures are contained in section 4 of the APA. Section 4(a) provides: 
data, views, or arguments. ${ }^{14}$ These simple "notice and comment" procedures, while permitting broad public participation in the formulation of rules, are at the same time calculated to avoid the delays and complexities of inore cumbersome adjudicative procedures. ${ }^{15}$ Moreover, in rulemaking, unlike adjudication, the agency's ability to utilize the advice of staff experts, outside experts, or relevant studies is not limited. ${ }^{16}$ Although ex parte contacts may be unfair to the individual hitigants in an adjudication, they are useful to lawmaking forums. ${ }^{17}$ Finally, after deciding to adopt a rule, the agency inust pubhish it in the Federal Register at least thirty days before its effective date. ${ }^{18}$

These ruleinaking procedures are aimed at providing a codified and published systein of rules of prospective operation, guaranteeing the affected seginents of the public a right to participate in rule developinent. By contrast, the adjudicatory procedures of the Administra-

General notice of proposed rule making shall be published in the Federal Register, unless persons subject thereto are named and either personally served or otherwise have actual notice thereof in accordance with law. The notice shall include-

(1) a statement of the time, place, and nature of public rule making proceedings;

(2) reference to the legal authority under which the rule is proposed; and

(3) either the terms or substance of the proposed rule or a description of the subjects and issues involved.

5 U.S.C. \& 553(b) (1976).

14. This right to comment is provided by section 4(b) of the APA: "After notice required by this section, the agency shall give interested persons an opportunity to participate in the rule making through submission of written data, views, or argunents with or without opportunity for oral presentation." Id. §553(c).

15. "Especially in the rapidly expanding realms of econounic, environmental and energy regulation, the policy disputes are too sharp, the technological considerations too coinplex, the interests affected too numerous, and the missions too urgent for agencies to rely on the ponderous workings of adjudication." Wright, supra note 1, at 376. These considerations motivated Congress in establishing separate rulemaking and adjudicatory proceedings, as suggested by the Senate report on the APA:

Proceedings are classed as rule making under this act not merely because, like the legislative process, they result in regulations of general applicability but also because they involve subject matter demanding judgments based on technical knowledge and experience. . . . In many instances of adjudication, on the other hand, the accusatory element is strong, and individual comphance or behavior is challenged; in such cases, special procedural safeguards should be provided to insure fair judgments on the facts as they may properly appear of record. The statute carefully differentiates between these two basically different classes of proceedings so as to avoid, on the one hand, too cumbersome a procedure and to require, on the other hand, an adequate procedure.

S. REP. No. 752 app. at 39. A recent congressional study reaffirmed this origimal asscssment of adjudicatory procedures, finding that rulemaking is a more expedient procedure for developing new standards. 4 Senate Comm. on Governmental Affalrs, 95th Cong., 1st Sess., Study on Federal Regulation 26-35 (1977).

16. The APA precludes "ex parte contacts" only during the course of adjudicatory proceedings. 5 U.S.C. $\S \S 554$ (d), 557(d) (1976).

17. "The technicalities of adjudication allow lawyers to minimize the input of experts and to frustrate agency consideration of relevant scientific and economic perspectives." Wright, supra note 1 , at 376.

18. Administrative Procedure Act $\S 4$ (c), 5 U.S.C. $\S 553(d)$ (1976). 
tive Procedure Act are backward-looking, "accusatorial" proceedings, with special procedural safeguards "designed not for the development of policy," but to provide an opportunity for the individual litigants to develop facts unique to thein. ${ }^{19}$ An examination of the text of the Administrative Procedure Act and its legislative history reveals that Congress intended rulennaking to be a mandatory process for development of law and policy, deliberately excluding adjudication as an alternative lawmaking procedure.

\section{A. Rule Formulation: Notice and Comment.}

Congress' reasons for mandatory rulemaking were grounded in the belief that responsiveness to the publie sector is inherent to lawmaking. The legislative history of the Administrative Procedure Act demonstrates that Congress intended its delegated lawmaking function to remain subject to public participation and scrutiny: "Day by day Congress takes account of the interests and desires of the people in framing legislation and there is no reason why administrative agencies should not do so when they exercise legislative functions which the Congress has delegated to them."'20 In addition to providing fair treatment of the interested public, this right of prior participation should promote public acceptance of agency rules.21

Apart from consideration of fairness and public acceptance, Congress also intended to promote more accurate lawnaking through the rulemaking process: valuable information can be gained front tlie public sector affected by agency action. As noted in the Senate Judiciary Cominittee report of the Administrative Procedure Act, "[agency] knowledge is rarely complete, and it must always learn the . . . viewpoints of those whom its regulations will affect. . . . [P]ublic participa-

19. See S. REP. No. 752 app. at 39.

20. APA LEG. History 359. The Senate Judiciary Committee Reports also emphasized that the "minimum requirement" of participation by the interested public was based on the "premise stated as follows by the Attorney General's Committee . . . : "An administrative agency . . . is not ordinarily a representative body. . . . Its deliberations are not carried on im public and its members are not subject to direct political controls as are legislators.' "Id. 19-20 (quoting ATT'Y GENERAL'S REP. 101-02).

21. For example, one court, faced with a challenge to the validity of an agency rule promulgated without rulemaking procedures, commented that "a meaningful prepublication dialogue between plaintiffs and the [agency] may have even avoided this lawsuit." Kelley v. United States Dep't of the Interior, 339 F. Supp. 1095, 1102 (E.D. Cal. 1972). See also APA LeG. History 20. The Attorney General's Report, whicl significantly influenced Congress' drafting of the APA, emphasized that while a reason for an "[agency's] existence is that it is expected to bring to its task greater familiarity with the subject than legislators, dealing with many subjects, can liave, . . . [agency procedures still] should be adapted to giving adequate opportunity to all persons affected to present their views, the facts within their knowledge, and the dangers and benefits of alternative courses." ATt'Y General's ReP. 102. 
tion ... in the rule-1naking process is essential in order to permit administrative agencies to inform themselves." 22

Congress clearly contemplated that, since the agency had educated itself through this broad-based rulemaking process, the reviewing courts would give the resulting rule considerable deference. ${ }^{23}$ When this process breaks down, and rules are developed instead by agency adjudications, courts may be more hberal in upholding or striking down the rules according to their own views, and bad law may result. Neither the agency nor the court is likely to possess the knowledge and expertise necessary to evaluate new standards without the education of the rulemaking process. Accordingly, Justice Harlan advocated that federal courts refuse to pass on the vahdity of new standards "until [the agency] has first illumined the regulatory problems involved through an appropriate exercise of its rule-making powers." 24

Fortunately, the courts are increasingly sensitive to the congressional goals of fairness to the public and education of the agency through the Administrative Procedure Act's notice and comment requireinents. In setting aside an agency action because of its failure to provide these procedures to the imdustry affected by the action, one court stated:

The interchange of ideas between the government and its citizenry provides a broader base for intelligent decision-1naking and proinotes greater responsiveness to the needs of the people, especially in

22. APA LEG. History 20 (quoting ATT'Y GENERAL's ReP. 102-03).

23. Congress, in section 10(e) of the APA, 5 U.S.C. $\$ 706(2)(E)$ (1976), authorizes judicial review of the substance of agency adjudications-at least to the extent of determining if the agency findings are based on "substantial cvidence." No such review of substance is provided for agency findings dcveloped by the rulemaking process.

24. California v. Lo-Vaca Gathering Co., 379 U.S. 366, 372 (1965) (Harlan, J., dissenting). To check the soundness of rules developed by the NLRB and the courts through adjudication, rather than through rulemaking, Professor Bernstein evaluated the "Fibreboard rule." This standard, developed out of agency adjudication and Supreine Court review thereof, is that "an employer contemplating the subcontracting of work being performed by employees represented by a umion has the obligation, under . . . the National Labor Relations Act, to bargain over [the merits of the subcontracting decision itself and not merely over its effect upon the employees involved." Bernstem, supra note 1, at 579. The Board offered the following statement in support of this bargaining requireinent: "Experience has shown, however, that candid discussion of mutual probleuns by labor and managenent frequently results in their resolution with attendant benefit to both sides. Business operations may profitably contimue and jobs may be preserved." Fibreboard Paper Prods., Corp., 138 NLRB Dec. 550, 551 (1962) (quoting Town \& Country Mfg. Co., 136 NLRB Dec. 1022, 1027 (1962)), reprinted in Bernstein, supra note 1, at 579. Professor Bernstein circulated a questiounaire among labor and nanageinent regarding the value of the Fibreboard rule. The result indicated that the NLRB had required labor and management to indulge in a charade, that the bargaining requirement had no practical value. A typical response said: "[W]e just go through the pretense of bargaining. It means inore lawyers' fees, but it makes no difference in the end." Id. 580. Professor Bernstein concluded that "an enormous number of Board doctrives are bascd upon untested suppositions." Id. 582. 
cases such as this where Congress has only roughed in its program. Indeed, a meaningful pre-publication dialogue . . . may have even avoided this lawsuit. ${ }^{25}$

The courts, however, have failed to recognize that these procedures are the exclusive process for developing law and pohcy, and that Congress deliberately precluded the agencies from using adjudication-which does not provide broad-based public input- to formulate rules. Nevertheless, careful attention to the text of the Administrative Procedure Act, and an examination of the relevant legislative history, shows that Congress purposefully integrated the various provisions of the Administrative Procedure Act to make notice and comment procedures mandatory. When an agency action constitutes "rulemaking," section 4 of the Administrative Procedure Act requires notice to interested parties and an opportumity for them to comment. Section 4 is mandatory: an agency "shall" give notice of "proposed rule making" and the agency "shall give interested parties an opportunity to participate in the rule making." 26 Simce these "notice and comment" procedures are mandatory for "rulemaking," it is necessary to define this term im order to determine the realm of agency action subject to these procedures.

"Ruleinaking" is the "agency process for formulatimg, amending, or repealing a rule."27 The Administrative Procedure Act defines a "rule" to encompass an agency's lawinaking and policymaking functions: a "rule" is a "statement of general or particular apphicability and future effect designed to implement, imterpret, or prescribe law or policy. . . ."28 In essence, a rule is a legal standard to be apphed prospectively to a class. ${ }^{29}$ The mclusion of the mapt phrase, "of . . . particular applicability," is simply to denote that a class can be sinall and can consist of named parties. ${ }^{30}$ "Rulemaking," then, is the development of standards of general applicability, that is, "rules." "Adjudication," on the other hand, is defined as the process for formulating an "order,"31 and, whatever the vagaries of the Administrative Procedure Act's defi-

25. Tasty Baking Co. v. Cost of Living Council, 395 F. Supp. 1367, 1389 (E.D. Pa. 1975); Kelley v. United States Dep't of Interior, 339 F. Supp. 1095, 1102 (E.D. Cal. 1972). See also Texaco, Inc. v. Federal Power Comm'n, 412 F.2d 740, 744 (3d Cir. 1969).

26. 5 U.S.C. $\$ 553($ b), (c) (1976) (emphasis added) (quoted at notes 13 \& 14 supra).

27. APA $\$ 2(c), 5$ U.S.C. $\$ 551(5)$ (1976) (emphasis added).

28. 5 U.S.C. $\$ 551(4)$ (1976).

29. With respect to the impact of a rule on a class, the Attorney General's Report makes this distinction between rules and adjudications: "[R]ules do not determine the rights of specific litigants, but, like statutes, are addressed to people generally.” ATT'Y GENERAL'S REP. 12.

30. 2 K. Davis, ADministrative Law Treatise $§ 7: 3$ (2d ed. 1979).

31. APA \& 2(d), 5 U.S.C. \& 551(7) (1976). 
nition of "order," 32 Congress clearly indicated that "[t]he term 'order' is essentially and necessarily defined to exclude rules." 33

Thus, the Administrative Procedure Act defines "rulemaking" in terms requiring notice and comment procedures for formulating law or policy, while excluding adjudicatory procedures. This construction of the statute is supported by the cominittee reports on the Administrative Procedures Act. The Senate report states that the "definition of 'rule' ... prescribes the kind of operation that is subject to section 4 [rulemaking] rather than section 5 [adjudication]." 34 Similarly, the House report states that the "definition [of a rule] is important because it determines whether section 4 rather than section 5 applies to a regulatory operation." 35

Congress, therefore, purposefully integrated the various provisions of the Administrative Procedure Act to make section 4 rulemaking procedures an exclusive method of developing law and policy. A problem of application is that this scheme requires the sometimes difficult task of determining whetler agency action constitutes a "rule"-prospective action having a "substantial impact" on the "rights or obhigations" of a class of people or an industry 36 - or an "order"-an ad hoc determination of the consequence of individual conduct affecting only the parties to the proceeding. ${ }^{37}$

\section{B. Rule Promulgation: Codification and Publication.}

In addition to prescribing procedures for agency formulation of law and policy, Congress also imposed codification and publication requireinents in order to inake the substance of agency-developed law and policy more accessible ${ }^{38}$ and to create a greater consistency in agency application of this law and policy. ${ }^{39}$ The ad loc development

32. Under APA section 2(d), " 'order' means the whole or a part of a final disposition . . . of an agency in a matter other than rule making . . ." 5 U.S.C. § 551(6) (1976).

33. H. ReP. No. 1980, 79th Cong., 2d Sess. 20 (1946), reprinted in [1946] U.S. CODE CONG. SERV. 1195; see S. Rep. No. 752 at 11.

34. S. REP. No. 752 at 11.

35. H. REP. No. 1980, supra note 33, at 20.

36. See text accompanying notes 115-33 infra.

37. Agency adjudication involves the resolution of "disputed facts, in particular cases." Umited States v. Florida East Coast Ry., 410 U.S. 224, 245 (1973); see S. Rep. No. 752 at 39.

38. E.g., APA LEO. HISTORY 15 ("an important and far-reaching defect in the field of public administration has been a simple lack of adequate public information concerning its substance and procedure").

39. The APA's codification and publication requirements are intended to avoid "the inherently arbitrary nature of unpublished ad hoc determinations." Morton v. Ruiz, 415 U.S. 199, 232 (1974); see United States ex rel. Parco v. Morris, 426 F. Supp. 976, 985-86 (E.D. Pa. 1977) (quoting Morton v. Ruiz, 415 U.S. at 232). 
of standards by adjudication is inconsistent with these purposes. Thus, on this additional basis, adjudication is an improper substitute for rulemaking.

Section 4 of the Administrative Procedure Act requires that agencies, in the exercise of the lawmaking authority delegated to them by Congress, must develop codified rules. These rules inust then be pubhished in the Federal Register at least thirty days prior to their effective date. ${ }^{40}$ Fmally, section 3(a) of the Administrative Procedure Act provides that no person will have "to resort to, or be adversely affected by, a matter required to be published in the Federal Register and not so published." 41

These codification and publication requirements proinote clarity by avoiding the uncertainties, delays, and costs to the public of ascertaining the law from the welter and mass of agency adjudicatory opinions. One commentator's discussion of the National Labor Relations Board's "contract bar rule," a rule developed through adjudication, illustrates the difficulties produced by an agency's failure to follow the codification and publication requirenents. The rule was perhaps intelligible for "anyone who has the time to put together all the cases in which different branches of the rule may be found, [and] to check all the recent decisions to inake sure that nothing has changed,"42 but for the most part "even experienced practitioners may be hard put to state ... . [such a] rule accurately." 43 Of course, it seems unfair to put interested parties to the expense of hiring a lawyer merely to state the rule. Requiring an agency to codify its law would alleviate such problems.

The codification and publication requirenents of the Administrative Procedure Act, however, accoinplish more than clarification of the law. Published rules bind the agency as well as the public. ${ }^{44}$ Thus, they achieve a greater uniformity and consistency in the application of the law than is possible when law is developed by the ad hoc process of adjudication. Indeed, experience has shown that lawmaking by adjudication lends itself to a certain arbitrariness, if not dissemblance, in the application of law by agencies. In one imstance, a change in Federal

40. APA § 4(c), 5 U.S.C. § 553(d) (1976).

41. 5 U.S.C. \& 552(a) (1976).

42. Shapiro, supra note 1 , at 941 .

43. Id. The burden of determining the substance of standards developed by adjudication also falls heavily on both the agencies and the courts. As one court wishfully noted with respect to NLRB practice, "[w] hat would truly ease the administrative problem both for the Board and for the courts would be for the Board to use its long neglected rule-making power to specify what a union authorization card should say and how." Bryant Chucking Grinder Co. v. NLRB, 389 F.2d 565, 570 (2d Cir. 1967), cert. denied, 392 U.S. 908 (1968) (footnotes omitted).

44. See, e.g., Unitcd Statcs v. Nixon, 418 U.S. 683, 694-96 (1974). 


\section{Communications Commission policy was}

slipped into an opinion in such a way that only careful readers would even know what had happened, without articulation of reasons, and with the prior authorities not overruled, so that the opinion writers remained free to pull them out of the drawer whenever the agency wislies to reach a result supported by the old rule but not the new. ${ }^{45}$

The Federal Communications Commission, lowever, in a more enliglitened decision, refused to subject inembers of the broadcast industry to the vagaries of agency application of uncertaim case law..$^{46}$ The substantive issue was whether a corporation could be represented by its own officers, rather than legal counsel, before the Federal Cominunications Commission Review Board. The Federal Communications Commission contended that "commission precedent" had establislied a rule allowing only attorneys to represent corporations. The Review Board recognized both that the Commission could formulate sucl a rule and that there were sound policy reasons for doing so. It found, lowever, that this "rule" was invalid on procedural grounds because it had not been published as required by section 3 and 4 of the Administrative Procedure Act. The Board noted that an uncertam case law could not substitute for published rules and "[w]hetler a corporation must be represented by counsel is a matter too fundamental, too general in applicability . . . to be made the subject of an ad hoc rule applicable when remembered . . . ."47

Similarly, the federal courts liave recently imported a new vitality to the Administrative Procedure Act's codification and publication requirements. A major Supreme Court decision, Morton v. Ruiz ${ }^{48}$ overturned an ad loc agency determination of ehgibility for government benefits because the Bureau of Indian Affairs failed to codify and publish its standards of eligibility. The Court leeld that the agency should have promulgated rules to "fill any gap" in its broad congressional delegation of autlority. Because the agency liad proceeded instead on an ad loc basis, the resulting standards were invalid. The Court emphasized that regardless of the substantive correctness of those determinations, they were invalid because "the agency must, at a mininum, lct the standard be generally known so as to msure that it is being applied consistently and so as to avoid both the reality and the appearance of arbitrary denial of benefits to potential beneficiaries."49 Regarding arbitrariness, the Court found that "[t]he Admmistrative Procedure Act

\footnotetext{
45. H. Friendiy, The Federal Administrative AgenCies 63 (1962).

46. Advanced Electronics, 21 F.C.C.2d 239 (1970).

47. Id. at 244.

48. 415 U.S. 199 (1974).

49. Id. at 231 .
} 
was adopted to provide, inter alia, that administrative procedures affecting individual rights and obligations be promulgated pursuant to certain stated procedures so as to avoid the inherently arbitrary nature of unpublished ad hoc determinations." 50

\section{Agency Implementation of Rulemaking.}

1. Agency Discretion. Recognizing a need for procedural flexibility in agency development of law and policy, Congress established the minimal requirements of notice to and opportunity to comment by the interested public, and of codified and pubhished standards. Otherwise, Congress left to the agencies the discretion to utilize additional procedures. This concept is explained by the Senate report:

This subsection states . . the minimum requirements of public rule making procedure short of statutory liearing. Under it agencies might in addition confer with industry advisory committees, consult organizations, hold infornal "hearing," and the like. Considerations of practicality, neccssity, and public interest . . . will naturally govern the agency's determination of the extent to which public proceedings should go. Matters of great import, or tlose where the public submission of facts will be either useful to the agency or a protection to the public, should naturally be accorded more elaborate public procedures. ${ }^{51}$

The Supreme Court recently emphasized Congress' belief that the Act is a statement of minimum essential rights and procedures in rulemaking and that "[a]gencies are free to grant additional procedural rights in the exercise of their discretion . ..."52 It would appear, therefore, that while the agencies enjoy discretion to utilize additional procedures beyond basic "notice and comment," they do not have discretion to avoid, by adjudication or otherwise, those procedures that Congress deemed essential to exercising the lawmaking functions dele-

50. Id. at 232. See also United States ex rel. Parco v. Morris, 426 F. Supp. 976, 985-86 (E.D. Pa. 1977). Moreover, there are constitutional overtones; in Hornsby v. Allen, 326 F.2d 605 (5th Cir. 1964), the court found that ad hoc application of standards by adjudication, in counection witl a municipality's liquor licensing, led to sucl arbitrariness in granting licenses as to violate equal protection. Accord, United States v. Cook, 445 F.2d 883 (8th Cir. 1971):

If the Selective Service intends to prosecute young men for failure to perform their obhgation to perform civilian service, we think, in the light of due process requirements, the Selective Service System must adopt well defined administrative rules and regulatious whicl articulate the standards of required performance and provide for appropriate notice of violations of those standards.

Id. at 890-91; Board of Pliarinacy v. Cohen, 448 Pa. 189, 200-02, 292 A.2d 277, 283-84 (1972).

51. S. REP. No. 752 at 14-15. Accord, H.R. REP. No. 1980, supra note 33, at 16-17 ("The bill is an outline of minimum essential rights and procedures. . . It affords private parties a ineans of knowing what their rights are and low they may protect them").

52. Vermont Yankee Nuclear Power Corp. v. Natural Resources Defense Council, Inc., 435 U.S. 519, 524 (1978). 
gated to agencies.

2. Enhancement of Agency Effectiveness. Studies of agency practice since the enactment of the Administrative Procedure Act have confirmed Congress' original conclusions that law and pohicy should be developed by the ruleinaking process. ${ }^{53}$ For example, the narrowness of the issues in adjudication, concentrated on the problems of the individual litigant, can preclude the overview of an imdustry necessary to establish suitable industry-wide standards. The Third Circuit has observed that rational decisionmaking concerning industry standards is not furthered by an agency losing "itself $i m$ an excursion into detail that too often obscures fundanental issues rather than clarifies them." 54 Moreover, expanding adjudicatory proceedings to allow participation by interested parties, even in an attempt to gam a broader perspective, results in imordimately lengthy and unmanageable proceedings. Thus, adjudicatory procedures have proven too cumbersome to entertain the wide variety of views necessary for the developinent of policy. ${ }^{55}$ The courts, and some agencies, have realized that rulemaking procedure, with its greater flexibility and efficiency, "opens up the process of agency policy innovation to a broad range of criticism, advice and data that is ordinarily less likely to be forthcoming im adjudication."56

Another advantage to the rulemaking process is reduced hitigation. By providing clearer standards to the affected industry or public, the codification and publication requirements tend to induce a greater compliance with these standards, without resort to litigation. Professor Davis, referring to "trade regulation rules" issued by the Federal Trade Commission, observed:

[A] single rule can sometimes have more effect on business practices than a hundred cease and desist orders. The fundamental is that nearly all businessinen will normally comply with law they understand. Spending a few hundred thousand of taxpayers' dollars for an order against a single company . . . might not pass any test concerning cost effectiveness . . ., but a trade regulation rule can declare

53. The general topic of advantages of rulemaking over adjudication has been cxammed in depth in other commentaries, see authorities cited in note 1 supra.

54. Bell Tel. Co. v. FCC, 503 F.2d 1250, 1266-67 (3d Cir. 1974), cert. denied, 422 U.S. 1026 (1975). See also Pacific Coast European Conference v. United States, 350 F.2d 197, 205 (9th Cir.), cert. denied, 382 U.S. 958 (1965).

55. Adjudicatory hearings become "totally unmanageable" when subjected to the broad public participation necessary for the development of policy. See Bell Tel. Co. v. FCC, 503 F.2d 1250, 1266 (3d Cir. 1974). For examples of the impracticability of industry-wide participation in adjudicatory proceedings, see W. Gellhorn \& C. BySE, AdMinistrative LaW, Cases \& CoMMENTS 733-35 (6th ed. 1974).

56. National Petroleum Refiners Ass'n v. FTC, 482 F.2d 672, 683 (D.C. Cir. 1973), cert. denied, 415 U.S. 951 (1974). 
such a practice unlawful, can apply to all and not just to a single respondent, and costs far less than a cease and desist order. ${ }^{57}$

Despite this general recognition of the superiority of rulemaking, the use of adjudication as a means of developing law and policy is not without its proponents. The Supreme Court, for exainple, has stated that an agency could choose to "proceed with caution, developing its standards in a case-by-case manner." 58 But a case-by-case process may result $\mathrm{m}$ an excessive particularization that precludes analysis of a problem as it relates to an imdustry as a whole and inhibits development of sound, clear standards. Perhaps the ultimate apology for the agency use of adjudication to develop law and policy is that "this is how the courts do it." One court, for instance, while observing that "some of the problems that arise in academia might better be addressed by rulemaking than by ad hoc case-by-case determination," 59 nevertheless approved the ad hoc practice, noting that it was "consistent with the common law method."60 What the court ignored, of course, was that Congress had provided a substitute for this "common law method." The Supreme Court, in a case arising prior to the enactment of the Administrative Procedure Act, reasoned that

[s]ince the [Securities and Exchange] Commission, unlike a court, does have the ability to make new law prospectively through the exercise of its rule-making powers, it has less reason to rely upon ad hoc adjudication to formulate new standards of conduct .... The function of filling in the imterstices of the Act should be performed, as much as possible, through this quasi-legislative proinulgation of rules to be applied in the future.61

Congress, by the Administrative Procedure Act, made this policy preference for rulemaking a part of statutory law.

\section{AN Obfuscation of the MaNdATE}

The rather clear requirement of rulemaking procedures has unfortunately been obscured by a series of Supreme Court decisions that are widely cited for the view that the Administrative Procedure Act, by providing both rulemaking and adjudicatory provisions, provides the

57. K. Davis, Administrative Law Treatise, § 6.18, at 292-93 (Ist ed. Supp. 1970). See generally Bernstem, supra note 1, at 592. The FTC itself has emphasized that rulemaking by adjudication is a "prohibitively time-consuming, costly, and inefficieut method of dealing with a problem common to an entire industry." FTC, Unfair or Deceptive Advertising and Labeling of Cigarettes in Relation to.the Health Hazards of Smoking, 29 Fed. Reg. 8324, 8368 (1964) (Statement of Basis and Purpose of Trade Regulation Rule).

58. NLRB v. Bell Aerospace Co., 416 U.S. 267, 294 (1974).

59. Trustees of Boston Univ. v. NLRB, 575 F.2d 301, 305 (Ist Cir.), petition for cert. filed, 47 U.S.L.W. 3097 (U.S. July 11, 1978) (No. 78-67).

60. 575 F.2d at 305 .

61. SEC v. Chenery Corp., 332 U.S. 194, 202 (1947). 
agency with the discretion to choose between these procedures for the development of law and policy.62 The opinion widely thought to be bedrock for such agency discretion is that of the Supreme Court in $S E C$ v. Chenery. ${ }^{63}$ This, however, is not a proper readimg of that case.

The usual view of Chenery rests on that Court's position that while an agency should ordmarily develop standards of conduct "through [the] quasi-legislative promulgation of rules to be applied im the future,"64 an agency may nevertheless proceed retroactively by adjudication to find past conduct illegal, even though such conduct has not been identified as illegal by an agency rule. ${ }^{65}$ This position, however, must be considered in context. First, the Court was not interpretimg or applying the Administrative Procedure Act; the agency action in question had occurred prior to the enactment of this statute. Indeed, the Court made no reference to the then newly enacted Administrative Procedure Act. Second, the Court's attention in Chenery was not directed to the problem of liow policy should be formulated. Instead, the Court was concerned with the retroactive application of new standards of conduct.

The Chenery case mvolved a Securities and Exchange Commission decision pursuant to a statute directing it to approve reorganization of public utility holding companies only when the reorganization was "fair and equitable to the persons affected."66 The Securities and Exchange Commission refused to approve a reorganization plan for a utility company unless inanageinent personnel sold the company stock that they had purchased durmg the reorganization. According to the Securities and Exchange Cominission, this stock ownership created a conflict of interest on the part of management, which was detimental to the corporation's shareholders. Management objected that such purchases were not illegal at the tinie of purchase; they contended that the Securities and Exchange Commission's new standard could not be retroactively applied to them-that it could only be "prospectively applied."67

The issue in Chenery, then, was retroactivity: could the Securities and Exchange Cominission condemn activity that was not illegal at the

62. See NLRB v. Bell Aerospace Co., 416 U.S. 267 (1974); NLRB v. Wyman-Gordon, 394 U.S. 759 (1969); SEC v. Chenery Corp., 332 U.S. 194 (1947).

63. 332 U.S. 194 (1947).

64. Id. at 202.

65. Id. at 202-03.

66. Public Utility Act of $1935, \S 11(\mathrm{e}), 15$ U.S.C. $\$ 79(\mathrm{k})(1976)$.

67. The Court summarized management's argument: "[T]he Commission would be free only to promulgate a general rule outlawimg sucli profits in future utility reorganizations; but such a rule would have to be prospective in nature and liave no retroactive effect upon the instant situation." 332 U.S. at 199-200. 
time it was performed? The adjudication vis-a-vis rulemaking question was raised because adjudication is typically retroactive in effect, involving judgments concerning past conduct, while rulemaking prospectively defines illegal conduct. The Court, therefore, was not confronted with the issue of the appropriate procedural method for formulating standards, nor was it concerned with the relevant Administrative Procedure Act requireinents. Properly viewed, Chenery relates to the procedure issue only by dictum that expresses a general preference for rulemaking - a preference made law by the Administrative Procedure Act. 68

This perception of the Administrative Procedure Act was subsequently accepted by a majority of the Court in NLRB v. WymanGordon Co. ${ }^{69}$ However, a plurahty of four in that opimion opted for a result that caused new confusion. Wyman-Gordon involved an attempt by the National Labor Relations Board to develop a rule of general apphication by adjudicatory procedures. Two employers had inailed antiunion material to their employees during the course of an election for union representation. The unions then asked the employers to furnish them with the names and addresses of those employees so that they could distribute rebuttal information. The employers refused. In the course of adjudication as to the propriety of the employers' action, the National Labor Relations Board has invited "certain interested parties to file briefs and to participate in oral arguments."70 At the end of the adjudicatory proceedings agamst these employers, the National Labor Relations Board announced a new standard, the "Excelsior Rule,"71 which was to apply prospectively "in all election cases." Under this standard, employers must provide a hist of employee names and addresses to the National Labor Relations Board who will then make the hist available to all parties to the election.

The Wyman-Gordon Company challenged the apphication of the Excelsior Rule to its particular case on the ground that the rule had not been formulated according to the rulemaking process of the Administrative Procedure Act. On review, the Supreine Court first noted that the Excelsior standard was, in fact, a rule enacted without meeting the rulemaking requirements of the Administrative Procedure Act. In particular, the National Labor Relations Board's imvitation to selected parties to intervene did not satisfy the requirement of notice to, and

68. Id. at 202. See text accompanying note 61 supra.

69. 394 U.S. 759 (1969).

70. Id, at 763 .

71. The Excelsior Rule had been promulgated originally in an earlier adjudicative proceeding, Excelsior Underwear, Inc., 156 N.L.R.B. 1236 (1966). 
opportunity to comment by, all interested parties. The National Labor Relations Board, however, argued that it had discretion to promulgate new rules in adjudicatory proceedings. Six of the Justices rejected this arguinent. Justice Fortas, for the plurahity of four, stated:

The rule-making provisions of that Act [APA], which the Board would avoid, were designed to assure fairness and a mature consideration of rules of general application . . . . They may not be avoided by the process of making rules in the course of adjudicatory proceedings. 72

The Court recognized that policy might be formulated in an adjudicatory proceeding, but that such policy was to be applied only to the parties to that proceeding. The plurahty did recognize that the result of an adjudication may serve to guide the "direction" an agency might take $\mathrm{m}$ the future. ${ }^{73}$ However, these recognized functions of adjudication did not justify the use of such a proceeding to develop standards that would affect substantially a large segment of the public. ${ }^{74}$ As Justices Douglas and Harlan poimted out, the Excelsior Rule was not "particularized to special facts"; rather, it was designed "to fit all cases at all times."75 Rulemaking procedures therefore were necessary.

Unfortunately, the plurality, while finding the National Labor Relation Board's procedures invalid, upheld the rule. Apparently, the plurality feit that the rule was substantively correct; therefore, a reinand for new proceedings to reformulate it would be "meaningless." But as Justice Harlan argued, how could the Court presuine to assess the merits of the rule when the Board liad not "recanvass[ed] all of the competing considerations" 77 in a rulemaking proceeding. The three remaining Justices concurred with the plurality's approval of the Excel-

72. 394 U.S. at 764.

73. Id. at 765-66. The plurality's statement concerning the limited role of adjudication in the formnlation of policy-policy as "applied and announced therem"-seems to indicate that an agency may, in appropriate circumstances, apply a statute directly without first implementing it by rules. Sucli circumstances might be that the statute is precise enough to be applied without implementation by rules, that in enforcing a statute an agency did not foresee a certain problem, or that the conduct in qnestion is rare and isolated. In such cases the public intercst may require that the statute be directly applied by adjudication. See SEC v. Clienery Corp., 332 U.S. 194, 201-03 (1947). This authority, lowever, does not indicate that the agency can generalize the result of the adjudication and apply it to a segment of the public without complymg with the rulemaking process.

74. Wyman-Gordon lias been cited for the assertion that "it is well established that agencies may articulate policies, interpret rules, and develop guidelines in the course of adjudication proceedings, so long as adjudication is not used as a substitute for substantive, legislative rulemaking." Human Resources Management, Inc. v. Weaver, 442 F. Supp. 241, 251 (D.D.C. 1978).

75. 394 U.S. at 777.

76. Id. at 766 n.6. The two dissenting Justices and the three concurring Justices all disagreed; they believed strongly that a procedurally invalid agency action could not be upheld.

77. Id. at 783 . 
sior Rule, but this concurrence was based on their belief that the Administrative Procedure Act gave an agency the discretion to use either adjudicatory or rulemaking procedures as the means of formulating a rule. ${ }^{78}$ As a result, the case is often taken to support such discretion.

In sum, Justice Fortas' opinion tried to recognize the rulemaking process as the exclusive means for developing agency policy, but because the plurality uplreld the rule despite its procedural deficiencies, the case proved to be less than dispositive.

The rulemaking vis-a-vis adjudication problem again came before the Supreme Court in NLRB v. Bell Aerospace Co. ${ }^{79}$ The federal labor laws contain no provision expressly exempting "managerial employees" from their coverage. Nevertheless, prior to 1970, the National Labor Relations Board had never certified a bargaining unit consisting of managerial employees, and the Board had indicated that such employees were not subject to the labor laws. ${ }^{80}$ In 1970, the Board changed its position and, in an adjudicatory proceeding, announced that these laws applied to all management employees except those wlio iniglit be placed im "conflict of interest situations" because of competing management and union interests. ${ }^{81}$ The Second Circuit, lowever, overturned the Board's action. The court thought that this new standard should be formulated by rulemaking procedures, ratlier than the adjudicatory procedures used by the Board. Judge Friendly, writing for the court, stated that "if the . . opinions of six justices in Wyman-Gordon are to mean anything, they must be read as demanding rule-making here." 82

On review, the Supreme Court disagreed. First the court revised the content of the Board's new standard. It found that Congress intended that all "managerial employees"-tlrose who "formulate and effectuate inanagement policies" and not just those in the more limited conflict of interest situation posited by tlie Board-were excluded from the protections of the labor laws. ${ }^{83}$ The Court remanded the case for the Board to determine whetlier the buyers were managerial employees according to this standard. On the issue of which procedures sliould be used by the Board in assessimg the status of the buyers im question, lowever, the Supreme Court held that the Board could apply this cor-

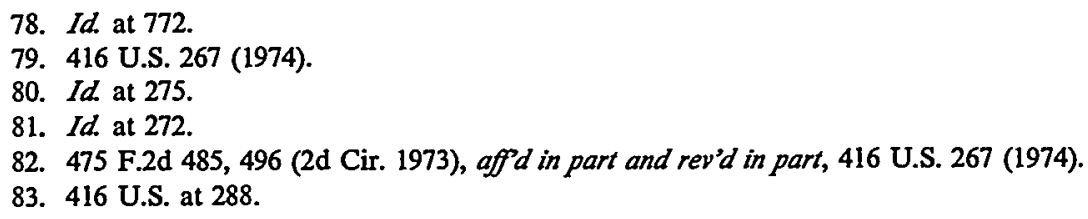


rected standard of "inanagerial employees" in an adjudicatory proceeding-without resort to rulemaking. ${ }^{84}$ This result is not necessarily inconsistent with the rulemaking requirements of the Administrative Procedure Act. If, on remand, the Board's task was siniply that of applying a legal standard to the twenty-five buyers, then the Board would not be formulating standards of general applicability; thus rulemaking would not be required by the Administrative Procedure Act. According to Judge Skelly Wright's reading of the opinion, the Supreme Court had thus "reserved the question whether the Board would have to use rulemaking to adopt a new standard of general applicability."85

The Court's treatment of the rulemaking problem in Bell Aerospace, however, is questionable. The problem is the manner in which the "inanagerial einployee" standard initially developed. The Board had formulated the standard by adjudicatory processes, and the Supreine Court on review revised the standard in accordance with its own views. Missing froin this process was any notice to or opportunity to comment by labor and management at large, and the attendant ability to "recanvass all of the competing considerations." 86 Judge Friendly, writing for the Second Circuit, thought that rulemaking was necessary:

The Board was prescribing a new policy, not just with respect to 25 buyers in Wheatfield, N.Y., but in substance . . . "to fit all cases at all times." There must be tens of thousands of manufacturing, wholesale and retail units which employ buyers, and luundreds of thousands of the latter. Yet the Board did not even attempt to imform industry and labor organizations . . . of its proposed new policy and to invite comment thereon $\ldots .{ }^{87}$

The Supreine Court in Bell Aerospace may have addressed ob-

84. The Court discussed the rulemaking issue in the following context:

The question is not whether the Board should have resorted to rulemaking, or in fact improperly promulgated a "rule" when in the context of the prior representation proceeding it held that the Act covers all "managerial employees" except those meeting the new "conflict of imterest in labor relations" touchstone. Our conclusion that the Board applied the wrong Icgal standard makes consideration of that issue unnecessary. Rather, the present question is whether on remand the Board unust invoke its rulemaking procedures if it determines in light of our opinion, that these buyers are not "managerial employees". ...

Id. at $291-92$.

85. Judge Wright's full statement was that

in Bell Aerospace the Court held merely that in deciding whether the buyers who worked for a particular employer were managerial employees the NLRB was free to proceed by adjudication. The Court expressly reserved the question whether the Board would have to use rule making to adopt a new general standard for determining when an einployee is a managerial employee.

Chisholm v. FCC, 538 F.2d 349, 390 (D.C. Cir.) (emphasis added) (footnotes oinitted), cert. denied, 429 U.S. 890 (1976).

86. NLRB v. Wyman-Gordon Co., 394 U.S. 759, 783 (1963).

87. 475 F.2d at 496 . 
hiquely the matter of the elimination of the rulemaking process in the initial formulation of the managerial employee standard. Although it first stated that the problem before it was the application of an already established standard to the twenty-five buyers im question, the Court, im a more expansive vein, cited Chenery and Wyman-Gordon for the proposition that "the Board is not precluded from announcing new primciples in an adjudicative proceeding and ... the choice between rulemaking and adjudication lies in the first instance within the Board's discretion." 88 These words encourage a broad interpretation that the Board could reverse its position and declare that all buyers are managerial enployees without resort to rulemaking. Because of such remarks, the Bell Aerospace opinion is now widely cited for the proposition that agencies can develop rules by adjudication. ${ }^{89}$ More limited and more careful readings of the opinion, such as that of Judge Skelly Wright, ${ }^{90}$ are rare.

The Supreme Court itself, however, in a decision rendered in the same term as Bell Aerospace, imdicated that agency developinent of new principles and standards must be by the rulemaking process. In Morton v. Ruiz, ${ }^{91}$ the Court overturned an ad hoc determination of inehgibility for federal funds because the agency had not established and published the eligibility standards im accordance with the rulemaking process of the Administrative Procedure Act. Adjudication, as a means of developing new standards, necessarily involves the "ad hoc" decisionmaking and uncodified standards that the Court disfavored in Ruiz. Therefore, to read Bell Aerospace as approving the ad hoc development of rules is to have the Court advancing in different directions on the same problem within the same term. Moreover, the mandate of Congress is controlling, and Congress has clearly made the rulenaking process mandatory for the development of new standards. Accordingly, the better view of the Supreme Court's position follows this congressional mandate: the Court in Chenery stated a policy preference for rulemaking, and then later in Wyman-Gordon and Ruiz recognized the mandatory directive of Congress on this point. Bell Aerospace may be somewhat out of line, but it is not necessarily a statement that an agency can formulate new standards by adjudication rather than rulemaking.

88. 416 U.S. at 294.

89. E.g., NLRB v. Children's Baptist Home, 576 F.2d 256, 260 (9th Cir. 1978); Giles Lowery Stockyards v. Department of Agriculture, 565 F.2d 321, 325 (5th Cir. 1977), cert. denied, 436 U.S. 957 (1978); Apex Oil Co. v. FEA, 443 F. Supp. 647, 655 \& n.6 (D.D.C. 1977).

90. See note 85 supra and accompanying text.

91. 415 U.S. 199 (1974). See text accompanying notes 48-50 supra. 


\section{The Application of the Rulemaking Mandate}

\section{A. The "Substantive Rules" Approach.}

The courts' reluctance to enforce rulemaking procedures can be attributed largely to the difficulty in determining the sphere of agency action for which such procedures are required.92 In the past, this problein was magnified by what now appears to be an unworkable and unnecessary approach.

Section 4 of the Administrative Procedure Act hsts two primary exceptions to rulemaking: interpretive rules and general statements of pohcy. ${ }^{93}$ Congress wished to encourage these informational functions, ${ }^{94}$ but, at the point that agency action becomes more than merely information and affects the rights and obhgations of the public, Congress intended to guarantee a right of prior public participation. ${ }^{95} \mathrm{Ex}-$ cept for interpretive rules and policy stateinents, therefore, Congress inade notice and comment procedures mandatory for the general body of rules.

Commentators and the courts nevertheless initially concluded that Congress meant notice and comment procedures to be mandatory only for certain kinds of rules- "substantive" rules. 96 Section 553, on its

92. Bernstein, supra note 1 , at 610 ; Shapiro, supra note 1 , at 924 .

93. APA § 4(a), 5 U.S.C. § 553(b) (1976).

Neither "interpretive rules" nor "general statements of policy" are defined by the APA. Interpretive rules are considered to be public statements of the agencies' view of the meaning of "statutory language" or of other rules and regulations. See ATT'y GenERAL's Rep. 27. See Bonfield, Some Tentative Thoughts on Public Participation in the Making of Interpretive Rules and General Statements of Policy Under the A.P.A., 23 AD. L. REv. 101, 108 (1971). "General statements of policy" serve thc function of informing the agency staff; they are "rules directed primarily at the staff of an agency describing how it will conduct agency discretionary functions, while other rules are directed primarily at the public in an effort to impose obligations on them." Noel v. Cliapman, 508 F.2d 1023, 1030 (2d Cir. 1975) (quoting Bonfield, supra at 117), cert. denied, 423 U.S. 824 (1976); see United States ex rel. Parco v. Morris, 426 F. Supp. 976, 984 (E.D. Pa. 1977). See generally Bonfield, supra at 117.

For purposes of determining the applicability of rulemaking procedures, these interpretive rules and general statements of policy exceptions are presently distinguished according to whether they have a "substantial impact" on the "rights and obligations" of a segment of the public. If therc is such an effect, then these exceptions cannot be claimed and the rulemaking process cannot be avoided. See text accompanying notes 115-17 \& 130-33 infra.

94. "[I]t is desired to encourage thc making of such rules." APA LEG. History 18. Nevertheless, the legislative history states that in situations in which rulemaking procedures are "useful" to the agency or "helpful to the public," agencies should not use the interpretive rules or general statements of policy exceptions to, avoid rulemaking. S. REP. No. 752 at 14.

95. See text accompanying notes 116-17 \& 130-33 infra.

96. Asimow, Public Participation in the Adoption of Interpretive Rules and Policy Statements, 75 MiCH. L. REv. 520, 530 (1977); Warren, The Notice Requirement in Administrative Rulemaking: An Analysis of Legislative and Interpretive Rules, 29 AD. L. REv. 367, 369 (1977). See also Pacific Gas \& Elec. Co. v. FPC, 506 F.2d 33, 39 (D.C. Cir. 1974). 
face, does not limit the rulemaking requirements to substantive rules; ${ }^{97}$ however, this limitation was imputed as consistent with the intent of Congress. ${ }^{98}$ Instead of being consistent, however, this interpretation resulted in a digression from congressional intent because of the definition of a substantive rule.

\section{A substantive rule was understood to be a rule having "the force of law":}

A properly adopted substantive rule establishes a standard of conduct which has the force of law. In subsequent administrative proceedings involving a substantive rule, the issues are whether the adjudicated facts conform to the rule and whether the rule should be waived or apphed in that particular instance. The underlying policy enbodied in the rule is not generally subject to challenge before the agency. ${ }^{99}$

Unfortunately, the actual impact of the rule on the public was not necessarily examined in determining whether a rule had the force of law. Rather, the key determinants were whether Congress had authorized an agency to make rules with the force of law and whether the agency had characterized the rule in question as having the force of law. ${ }^{100}$

97. One court noted that the characterization as substantive was not very helpful and moreover, that the "word 'substance' nowhere appears in section 4(a) [of the APA]." National Motor Freight Traffic Ass'n v. United States, 268 F. Supp. 90, 96 (D.D.C. 1967), affd per curiam, 393 U.S. 18 (1968).

98. While the text of the APA does not limit notice and comment procedures to substantive rules, it does refer to the necessity of publishing "substantive" rules. APA \& 4(c), 5 U.S.C. § 553(d) (1976). The import of this distinction is not clear from the legislative history. Perhaps Congress, while it did not by the text of scction 553 inake "notice and comment" procedures applicable only to "substantive rules," understood nevertheless that this would be the usual realm of rulemaking. The Senate report states that public rule making procedures are required only for "substantive rules, whicl involve true administrative legislation." APA LEG. HISTORY 19. The problen, though, has not been that notice and comment procedures may be available only for "substantive rules"; rather, the problem has been the limited and unrealistic definition of substantive rules.

99. Pacific Gas \& Elec. Co. v. FPC, 506 F.2d 33, 38 (D.C. Cir. 1974).

Another aspect of the substantive rule approach was that the courts would not substitute their views for that of the agency rcgarding the inerits of a substantive rulc. But in the case of a lesser kind of rule, for example an interpretive rule, the courts might consider the merits of the rule de novo. "While the legislative regulation [substantive rule], if intra vires, must be applied by the courts, the interpretive regulation, being "only an extrinsic aid in deciphering the meaning of an ambiguous statute,' may be refused judical recognition." Morgenthau, Implied Regulatory Powers In Administrative Law, 28 Iowa L. Rev. 575, 582 (1943). See also Gibson Wine Co. v. Snyder, 194 F.2d 329, 332 (D.C. Cir. 1952). The problem with this distimction is that it does not sufficiently account for the practice of the courts, whicls often look to factors other than the substantive rule-interpretive rule definitional scheme in assessing the deference to be given an agency rule. Such factors include the expertise of the court with respect to the subject inatter of the rule, whether the rule is a longstanding one, whether the statute has been reenactcd with the rule outstanding, etc. The result is that so-called "interpretive rules" are often constructions of the law with authority equal to that of substantive rules. See $1 \mathrm{~K}$. DAVIS, ADMINISTRATIVE LAW TREATISE, §§ 5.05-.07 (1st ed. 1958).

100. For example, Professor Davis states that 
Some problems are readily apparent. First, with or without specific congressional authority to make rules, an agency must interpret and apply the statute under which it operates, an action often mvolving a formulation of law and policy with significant effect on the public. Second, an agency that has been given rulemaking authority may characterize its action as something other than a rule witl legal force even though the action significantly affects the "rights and obligations" of the public. In these situations, the impact of the agency action on the public should raise the issue of the right of prior participation in the formulation of the action provided by rulemaking procedures. The substantive rule test, however, did not admit this kind of analysis.

To illustrate, in Gibson Wine Co. v. Snyder ${ }^{101}$ the agency had mitially promulgated a regulation that "[f]ruit wime derived wholly . . . from one kind of fruit shall be designated by the word 'wme' qualified by the name of such fruit . . ."102 Later, the agency decided that wime made from the boysenberry, a variety of a blackberry, could not be labeled as blackberry wine. The Gibson Wime Company challenged this decision on the basis that it amended an existing regulation, hence requiring rulemaking procedures. The court, however, noted that the agency had identified its action as merely an "imterpretation" of an existing regulation; thus, the action did not have the force of law. Since the action lacked the force of law, rulemaking procedures were not required. ${ }^{103}$ According to the dissent, however, the question was not the agency's characterization of its action; rather, it was whether the action in fact deprived a boysenberry wime producer of a "valuable right," thereby raising the issue of prior participation in the agency decision. ${ }^{104}$

A more recent application of the "force of law" standard occurred in Pacific Gas \& Electric Co. v. FPC. ${ }^{105}$ This case involved Federal Power Commission attempts to curtail natural gas usage. Curtailment

[a] rule which the agency designates as interpretive and as 'merely declarative of the Commission's view' is surely an interpretive rule. That $\$ 4$ of the Administrative Procedure Act exempts 'mterpretive rules' from its procedural requirements, coupled with the Commission's omission of such procedures, contributes to the classification of rules as interpretive.

K. DAvis, supra note 57, $\$ 5.03$, at 249. See also Asimow, supra note 96, at 557 ("The traditional test [of determining the applicability of rule inaking] relies to an unacceptable degree on the label used by the agency").

101. 194 F.2d 329 (D.C. Cir. 1952).

102. Id. at 330 .

103. Id. at 331-32.

104. Id at 335 (Miller, J., dissenting). The dissent also noted that "the new ruling has the force and effect of law, as far as the Gibson Wine Company and others similarly situated are concerned," no matter how the agency characterized it. Id. at 335-36. This view antedates the more modern approach, discussed at notes 115-33 infra and accompanying text.

105. 506 F.2d 33 (D.C. Cir. 1974). 
measures could be based either on the order of "contract commitments" to customers or on the nature of the customer's "end use" of gas. By a promulgation labeled a "Statement of Policy," the Commission annonnced that the curtailment was to be based on the "end use" of the gas. This "Statement of Pohcy" was issued without prior notice to, or comment by, the regulated industry. Consequently, customers whose gas supplies were subject to curtailment souglit to overturn it. The court, however, found that the agency had not intended the statement in question to have the "force of law." Accordingly, it was not a "substantive rule" requiring rulemaking procedures. ${ }^{106}$

The flaw in this decision is that the court ignored the real, immediate impact of the agency action. As stated by one commentator:

[The policy statement] had an immediate effect on all gas customers who had contractual commitments for deliveries, but low [end use] priorities, and who had every reason to take the FPC's pronouncement seriously. The chance of obtaining a waiver in subsequent proceedings would have appeared to them to be extremely slight. Consequently, low priority customers had to begin an immediate search for alternative energy sources, to negotiate long-range commitments for other fuels, and to purchase equipment for burning them. 107

A more forthright approach would have been to recognize that the Federal Power Commission had selected a gas curtailment policy likely to have a substantial effect on existing contract rights of a segment of the industry. The industry's right of prior participation in the formulation of this policy would then lave been in issue. ${ }^{108}$

The artificial, unedifymg substantive rule test was not the only weakness in the court's decision. The court enployed a curious sort of bootstrapping in its adherence to the usual view that the Federal Power Commission could develop rules by either adjudication or rulemaking. ${ }^{109}$ Froin this position, the court reasoned that

[a]lthough the Commission is free to initiate a rulemaking proceed-

ing to establish a binding substantive rule, the Commission appar-

106. The court first stated that rulemaking procedures applied only to substantive rules. $I d$. at 37. It then defined a substantive rule as a rule having "the force of law." Id. at 38. The court concluded that the statement of policy did not have "the force of law," primarily because the agency had characterized its action as one without "legal effect." In this respect, the court explained that "the stated purpose . . . was not to provide an infiexible binding rule." Id. at 40-41.

107. Asimow, supra note 96 , at 536-37.

108. If the FPC had wished to avoid rulemaking because of emergency conditions created by the gas crisis, it could have done so pursuant to section 4(a) of the APA, which provides that "notice and comment" procedures may be dispensed with "when the agency for good cause finds (and incorporates the finding and a brief statement of reasons therefore in the rules issued) that notice and public procedure thereon are impracticable, unnecessary, or contrary to the public interest." 5 U.S.C. \& 553(b) (1976).

109. 506 F.2d at 38. 
ently intends to establish its curtailment policies by proceeding througl individual adjudications. Order No. 467 merely announces the general policy which the Commission lopes to establish in subsequent proceedings. 110

The court, therefore, thought a general statement of policy preferable to springing a "secret policy" on the public by the "ad hoc" process of adjudication. ${ }^{111}$ Thus, the court acted as it did in large part to provide a means of aneliorating the ill effects of developing law by adjudication. The fact reinains, however, that the "policy stateinent" itself would cause natural gas custoiners with existimg contract commitments to forego their contracts and look to alternative sources. Moreover, if the ruleinaking process had been recognized as the required means of formulating policy, the "secret policy" problem that troubled the court would have disappeared.

Another disturbing aspect of both the Gibson and Pacific Gas cases is the courts' assumption that because the agencies had characterized their actions as having no legal effect, the courts could review those actions de novo, and therefore, plenary judicial review would save the parties froin being prejudiced by the agency actions. ${ }^{112}$ But this preinise is a serious perversion of the agency-court partnership contemplated by Congress. If the agency action had been imbued with a sense of fairness and acceptability by prior public participation, perhaps the "arduous" litigation would have been avoided in the first place. ${ }^{113}$ More important, the court does not possess this presuined ability to assess the underlying wisdoin of the agency action. Congress intended that law and policy be determined through agency expertise, assisted and educated by the interested public. Congress did not intend that the substantive basis of policy be determined de novo first by the court and then in a proceeding in which only certain nnembers of the affected industry participate. Again, Justice Harlan's admonition is on point:

110. Id. at 41 .

111. Id.

112. Gibson Wine Co. v. Snyder, 194 F.2d 329, 332 (D.C. Cir. 1952) ("The District Court treated the Deputy Commissioner's ruling as a inere expression of opinion, examined the whole question on the inerits de novo ab initia, made its own findings on the evidence before it, and reached its own conclusions upon the merits"). Pacific Gas \& Elec. Co. v. FPC, 506 F.2d 33, 40 (D.C. Cir. 1974). The statements in Pacific Gas are dictum, since that court conteinplated review of the substance of the policy stateinent at some later time, perhaps after this statement was applied in adjudication. But the court noted that the scope of this future review would be "broader than the scope of review for a substantive rule," since a policy statement could be issued without prior public participation. Id. at 49.

113. "I do not understand why the Deputy Commissioner was so loath to grant [a hearing] in this case. To do so would have been inuch less arduous and time-consuming than to engage in this litigation." Gibson Wine Co. v. Snyder, 194 F.2d 329, 336 (D.C. Cir. 1952) (Miller, J., dissenting). 
The "court should decline to pass upon these cases until the [agency] has first illumined the regulatory problems involved through an appropriate exercise of its rule making powers." 114

\section{B. The "Substantial Impact" Approach.}

Eventually, it became evident that the substantive rule test obscured rather than clarified. The Second Circuit discarded the substantive rule approach, stating, "[t]he label that the particular agency puts upon its given exercise of administrative power is not, for our purposes, conclusive; rather, it is what the agency does in fact." 115 Under the new approach, if agency action significantly affects the "right or obligations" of a regulated industry or a segment of the public, then that action should be put "to the test of prior examination and comment by the affected parties." 116 Such agency action satisfies the Administrative Procedure Act's definition of a rule. ${ }^{117}$

This "substantial impact" test originated in the Third Circuit's 1969 decision in Texaco, Inc. v. Federal Power Commission. 118 The Federal Power Commission, without prior public participation, had imposed a requirement of compound rather than simple rates of interest on certain refunds. To avoid ruleinaking procedures, the Federal Power Comunission characterized its action as a "policy stateunent." However, the court set aside the agency action because of the Federal Power Commission's failure to adhere to the rulemaking process:

[The rulemaking procedure] was enacted to give the public an opportunity to participate in the rule-nıaking process. It also enables

114. California v. Lo-Vaca Gathering Co., 379 U.S. 366, 372 (1965) (Harlan, J., dissenting). See text accompanying note 24 supra.

115. Lewis-Mota v. Secretary of Labor, 469 F.2d 478, $481-82$ (2d Cir. 1972). This court, looking to what "the Director in fact did," rejected the agency's characterization of its action and imposed a ruleinakimg requirement where the action actually affected "existing rights and obligations" of a class. Id. at 482. A similar approach was utilized by a three-judge court in the District of Columbia Circuit: "The characterizations 'substantive' and 'procedural'-no more here than elsewhere in the law-do not guide inexorably to the right result, nor do they really advance the inquiry very far." National Motor Freight Traffic Ass'n v. United States, 268 F. Supp. 90, 96 (D.D.C. 1967), aff'd per curiam, 393 U.S. 18 (1968).

116. Phillips Petroleum Co. v. Department of Energy, 449 F. Supp. 760, 799 (D. Del. 1978) (quoting Natioual Helium Corp. v. FEA, 569 F.2d 1137, 1146 (Emer. Ct. App. 1978)), affd sub nom. Standard Oil Co. v. Department of Energy, 596 F.2d 1029 (Einer. Ct. App. 1978). In these instances, the courts realize readily that Cougress intended prior public participation: "[T]he basic policy [section 4 of the APA] requires that when a proposed regulation of general applicability has a substantial impact on the regulated industry, . . . notice and opportunity for comment should . . be provided." American Ass'n of Councils of Medical Staffs v. Mathews, 421 F. Supp, 848, 857 (E.D. La. 1976) (quoting Pharnaaceutical Mfrs. Ass'n v. Finch, 307 F. Supp. 858, 863 (D. Del. 1970)).

117. See text accompanying note 28 supra.

118. 412 F.2d 740 (3d Cir. 1969). 
the agency promulgating the rule to educate itself before establishing rules and procedures which have a substantial impact on those regulated. ... These procedures must be followed when an agency is exercismg its legislative function . . . . 119

The impact on the regulated industry was evident: a higher interest rate.

The decision in Pharmaceutical Manufacturers Association $v$. Finch ${ }^{120}$ illustrates the usefulness of analyzing the impact on the regulated industry to determine whether prior notice and comment requirements apply. In 1962, the Food, Drug, and Cosmetic Act ${ }^{121}$ was amended to require that the "effectiveness" of new drugs be estabhished by "substantial evidence."122 A few years later, the Food and Drug Administration, without prior public participation, issued regulations prescribing standards for "adequate and well-controlled clinical investigations," wlnch the Food and Drug Admimistration would consider sufficient to estabhsh "substantial evidence" of the "effectiveness" of drugs. ${ }^{123}$ All other documented clinical evidence and clinical tests were excluded as "irrelevant." 124 Characterizing this regulation as "interpretive and procedural," the Food and Drug Administration contended that it was exeinpt from ruleinaking requireinents. ${ }^{125}$

The court, however, found that "a facile semantic distinction between an 'interpretive and procedural' rule on the one hand and a 'substantive' rule on the other does little to clarify whether the regulations here mvolved are subject to the notice and comment provisions of Section 4 . . ."126 Rather, the "basic purpose" of the Administrative Procedure Act's rulennaking requirement considered in light of the rule's "impact on the regulated industry" was the better approach.127 Accordingly, the court found that the new regulation changed the evidentiary standards relating to the removal of drugs from the inarket, was "pervasive" in that it applied to more than 2,000 drug products, and had an "immediate and substantial impact" on the way drug coinpanies conducted their "every day business." 128 Also, the court noted

119. Id. at 744 (emphasis added).

120. 307 F. Supp. 858 (D. Del. 1970).

121. 21 U.S.C. $\$ \S 301-392(1976)$.

122. Pub. L. No. 87-781, § 102(d), 76 Stat. 780 (1962) (codified at 21 U.S.C. $\S 355(e)$ (1976)).

123. 21 C.F.R. $\& 130.12$ (1970).

124. Id. Moreover, should the FDA attempt to remove a drug from the market because of lack of effectiveness, a drug company could obtain a hearing only if it demonstrated an ability to show "substantial evidence" of the kind demanded by the regulation. 307 F. Supp. at 860.

125. 307 F. Supp. at 863 .

126. Id.

127. Id. at 863 .

128. Id. at 864 . 
that there was "considerable confusion" as to the substantive validity of the regulation and that many questions had arisen that might be avoided by the agency's educating itself through rulemaking proceedings. ${ }^{129}$

The viability of this "substantial impact" test is indicated by the wide following that it has quickly gained annong the courts. ${ }^{130}$ Such broad application indicates that this approach provides analysis sufficiently precise to determine whether rulemaking is apphicable. In this respect, the "substantial impact" terminology is somewhat of an oversimplification. This approach first involves a determination of whether the effect of an agency action is sufficiently pervasive to be the legislative-like action for which Congress established ruleinaking procedures. Then the court must ask whether this action has a "palpable effect"131 or a "substantial impact" on the public or the industry subject to the action. Soinetimes the agency action clearly does not have a substantial impact-for example, when the agency is merely clarifying existing standards and not creating new ones. ${ }^{132}$ In close situations, courts should look to the "touchstone" of congressional purposes, ${ }^{133}$ such as creating a sense of fairness and acceptability with respect to agency standards, or usefully educating the agency by the rulemaking process.

129. The court stated that "the admimistrative procedures required by section $4 \ldots$ would at the very least provide an opportunity for clarifying some of the difficult problems and matters which, if unresolved, may impede effective enforcement of the Food and Drug Act." Id. at 868.

130. In addition to the cases already noted, see National Helium Corp. v. FEA, 569 F.2d 1137, 1145-46 (Emer. Ct. App. 1978); Anderson v. Butz, 550 F.2d 459, 462-63 (9th Cir. 1977); Pickus v. United States Bd. of Parole, 507 F.2d 1107, 1112-14 (D.C. Cir. 1974); Aiken v. Obledo, 442 F. Supp. 628, 648-50 (E.D. Cal. 1977); Lewis v. Wemberger, 415 F. Supp. 652, 659-60 (D.N.M. 1976); City of N.Y. v. Diamond, 35 Ad. L.2d 643 (S.D.N.Y. 1974); National Motor Freight Traffic Ass'n v. Umited States, 268 F. Supp. 90 (D.D.C. 1967), affd per curiam, 393 U.S. 18 (1968). Not surprisimgly, the "substantial impact" approach is now used to define "substantive" for purposes of section 4(c) of the APA, which requires publication of "substantive rules." This supplants the "legal effects" test. The "substantial impact" approach, therefore, applies uniformly to the rule publication as well as the rule formulation parts of the APA. Appalachian Power Co. v. Train, 42 Ad. L.2d 819, 822 (4th Cir. 1977); St. Elizabeth Hosp. v. United States, 41 Ad. L.2d 461 (Ct. Cl. 1977).

131. National Hehum Corp. v. FEA, 569 F.2d 1137, 1146 (Emer. Ct. App. 1978) ("When an agency action has 'palpable effects' upon the regulated industry and the public in general, it is necessary to expose that action 'to the test of prior exammation and comment by the affected parties" ") (quoting National Motor Freight Traffic Ass'n v. United States, 268 F. Supp. 90, 96 (D.D.C. 1976), aff'd per curiam, 393 U.S. 18 (1968)).

132. E.g., American Ass'n of Councils of Medical Staffs v. Mathews, 421 F. Supp. 848 (E.D. La. 1976).

133. The "touchstone . . . is the basic purpose" of Congress in establishing the rulemaking process. Phillips Petroleum Co. v. Department of Energy, 449 F. Supp. 760, 799 (D. Del. 1978), affd sub nom. Standard Oil Co. v. Department of Energy, 596 F.2d 1029 (Emer. Ct. App. 1978). 


\section{An Importation of "Substantial Impact" Analysis to the Rulemaking versus Adjudication Problems.}

The courts developed this "substantial impact" approach primarily to resolve problems of the apphicability of rulemaking requirements in situations in which agency action was characterized as an interpretive rule or a statement of policy. The "outer boundaries" of the exceptions to the rulemaking requirements are now circumscribed by the congressional purpose in enacting section 4-giving the interested public an opportunity to participate and insuring that the agency is fully inforined before it proinulgates rules having substantial impact. ${ }^{134}$ This approacl should similarly be used to determine the "outer boundaries" of adjudications. If standards developed by adjudication are generalized to have a "substantial impact" on an industry or a segment of the public, then the basic purpose of section 4 still requires notice to and an opportunity to comment by those subject to the standards. Indeed, Congress' concerns in establishing the rulemaking process apply more fully to standards developed by adjudication than to interpretive rules and general stateinents of policy. In adjudication proceedings, not only does the agency not have the benefit of public participation, but also, in the absence of codification and publication, the agency's position is unlikely to be defined clearly. Thus, development of rules through adjudication further frustrates the congressional purpose behind section 4.

The abuse of discretion test, which is normally applied in determining whether the agency should have used the rulemaking process, fails to consider that Congress' purpose in establishing the rulemaking process was to ensure fairness and accuracy in the formulation of policy. The abuse of discretion test is instead concerued with retroactivity, as deinonstrated in a recent Eighth Circuit case:

We entertain no doubt now that the Board does have the power to announce new principles of law in an adjudicatory proceeding. . . . In deciding whether to exercise that power, however, the Board must weigh the benefits to be achieved by the new interpretation of the law against the detrimental effects of retroactive apphication of the new rule. ${ }^{135}$

Consequently, consideration of the propriety of adjudication rather than rulemaking has been largely confined to the issue of injury to the individual litigants-injury in the sense that the agency had not yet

134. Anderson v. Butz, 550 F.2d 459, 462-63 (9th Cir. 1977); Pickus v. United States Bd. of Parole, 507 F.2d 1107, 1112 (D.C. Cir. 1974).

135. Drug Package, Inc. v. NLRB, 570 F.2d 1340, 1346 \& n.5 (8th Cir. 1978). See also Retail, Wholesale \& Dep't Store Union v. NLRB, 466 F.2d 380, 388-93 (D.C. Cir. 1972). 
held the individual actions to be illegal at the time the actions were taken. ${ }^{136}$ By focusing on the detrimental effect of retroactive application of standards, the abuse of discretion test ignores the way in which these standards are imitially formulated. ${ }^{137}$

This lack of attention to the manner of rule formulation is illustrated by a recent labor law decision. Although vested with jurisdiction over all cases "affecting commerce," the National Labor Relations Board, in order to "focus its resources," has formulated "discretionary jurisdictional standards." These standards had been developed by adjudication. ${ }^{138}$ In NLRB v. Children's Baptist Home, ${ }^{139}$ the respondent "Baptist Hoine," a nonprofit resident care center for emotionally disturbed children, became embroiled in a welter of conflicting National Labor Relations Board jurisdictional standards regarding nonprofit institutions. In response to a uinon petition for certification as the collective bargaining representative of Baptist Home employees, the National Labor Relations Board, relying on recent adjudications approving jurisdiction over similar institutions, determined that it also had jurisdiction over the Baptist Home. The Baptist Home did not then contest this determination. However, when the Board announced "a policy of declining jurisdiction over nonprofit child care centers"140 in another adjudication a year later, the Baptist Home naturally asked that this new policy of declining jurisdiction be applied to it. The Board, lowever, refused to relinquisli jurisdiction, and the certification proceedings continued. Then the Board, completely routing that hobgoblin of consistency, reversed itself again in anotlier adjudication, and returned to its initial standard of exercising jurisdiction over non-

136. This tying of the propriety of ruleinaking to the problem of retroactive agency action resnlts from the common overgeneralization of the Snpreme Court decision in SEC v. Chenery Corp., 332 U.S. 194 (1947). Chenery's disposition of a retroactivity problein unfortunately came to be regarded as a decision that an agency can, in its discretion, formulate law by adjudication rather than ruleunaking. See text accompanying notes 64-68 supra.

137. Also, the abuse of discretion test is contrary to APA reqnirements for rulemaking. The legislative history of the Act indicates that the only situation in which "discretion" exists is with respect to actions specifically excepted from the rulemaking requirement. For example, with respect to the section 4 exception from ruleınaking of matters relating to "public property, loans, grants, benefits or contracts," the House report states that

these exceptions are not to be taken as encouraging agencies not to adopt voluntary public rule making procedures where useful to the agency or beneficial to the public. They inerely confer a discretion upon agencies to decide what, if any, public rule inaking procedures shall be utilized in a given situation within their terms.

H. REP. No. 1980, supra note 33, at 23. See also text accompanying notes 51-52 supra.

138. NLRB v. Children's Baptist Home, 576 F.2d 256, 258 \& n.1 (9th Cir. 1978).

139. Id.

140. Id. at 258-59 (einphasis added). This reversal in jurisdictional standards was announced im Ming Quong Children's Center, 210 N.L.R.B. 899 (1974). 
profit child care homes. ${ }^{141}$ Relying on this latest standard, the Board finally rejected the Baptist Home's arguments that the Board should not exercise its jurisdiction and ordered the Home to bargain with the union.

The Baptist Home, before the federal court of appeals, argued that the Board's use of adjudicatory proceedings rather than rulemaking to set the jurisdictional standards was improper. Utilizing the "abuse of discretion intertwined with retroactivity" test, the court stated that the Baptist Hoine had the "burden of showing that the Board's actions were unfair and that the [Baptist Home] was to some degree prejudiced by that unfairness." 142 The court was unable to find that the Board's "two complete reversals on an important question of jurisdictional policy without the notice and comment safeguards were . . . unfair vis-avis the Hoines."143 The absence of rulemaking, "vis-a-vis the Home," was not considered unfair simce the origmal assertion of jurisdiction over the Home was consistent with the standard in effect when the Board's order was finally issued, ${ }^{144}$ never mind the vacillating standards in the interim.

Because it apphed the abuse of discretion analysis, the court had no call to consider whether Congress' purposes in establishing the rulemaking process were frustrated by the Board's refusal to use this process to develop jurisdictional standards. Had it done so, it probably would have found that a jurisdictional standard subjecting these nonprofit child care lomes to the labor laws did have a substantial impact on labor-management relations in this service industry. Thus, the imdustry was entitled to prior participation in the formulation of the standards. Moreover, Congress intended that the agency educate itself by public participation in order to achieve more accurate and enduring standards. Obviously, the National Labor Relations Board's erratic reversals of standards over a short period indicate the inconsistency of the adjudicatory process with that goal. Fimally, Congress intended that standards affecting the profession be stated im pubhished rules of uniform application. By contrast, the adjudicatory route resulted in inconsistency: one standard for one home, another standard for the second, then the origmal standard for the third, and so on. All these factors would have been exammed under the "substantial impact" approach to rulemaking versus adjudication problems; they were ignored under the prevailing abuse of discretion approach.

141. 576 F.2d at 259; see Rhode Island Catholic Orphan Asylum, 224 N.L.R.B. 1344 (1976).

142. 576 F.2d at 260.

143. Id.

144. Id. at $260-61$. 


\section{CONCLUSION}

Recognition that Congress established the rulemaking process as an exclusive means of developing standards that significantly affect the private sector should have the incidental effect of resolving certain problems plaguing administrative law. For example, President Carter is concerned with the proliferation of agency rules of questionable worth. ${ }^{145}$ Use of "the test of prior examination and comment by the affected parties"146 might eliminate the problems of a standard's suspect value and its acceptability to the affected public.

Another inodern concern is that the "delegation doctrine" has not been a successful means of curtailing unchecked and arbitrary agency lawniaking. ${ }^{147}$ This doctrine, a separation of powers concept, states that Congress should provide the agency with substantive standards for implenienting broad legislative provisions. Recognizing Congress' failure under this doctrine to supply standards sufficiently precise to prevent unconfined agency lawmaking, some courts and commentators suggest redefining the doctrine to shift it from a requirement of "statutory standards" to a requirement of "administrative standards" "provided by administrative rulemaking." 148 Their theory is that the agency will confine itself by rulemaking and publication of rules, thereby preventing the arbitrariness that can result from the ad hoc application of a broad statutory standard. This redefinition of the delegation doctrine, however, seems conceptually awkward, especially since the doctrine itself is a constitutional concept with a separation of powers basis. Imposition of rulemaking requirements to prevent arbitrary agency action is already justified because Congress, through the Administrative Procedure Act, has linked its delegation of lawmaking authority to the requirement that this authority be exercised pursuant to the rulemaking process.

Another current problen is an occasional agency propensity for abrupt and unexplained changes in policy. Such changes are usually the result of ad hoc adjudicatory processes, and the courts have inveighed against them. To illustrate, the Civil Aeronautics Board, by an adjudication, revoked air routes to two municipalities, contrary to its past policy supporting the continuation of the routes. The First Circuit

145. N.Y. Times, Mar. $26,1979, \S 1$, at 1, col. 1 .

146. Phillips Petroleum Co. v. Department of Energy, 449 F. Supp. 760,799 (D. Del. 1978) (quoting National Helium Corp. v. FEA, 569 F.2d 1137, 1146 (Emer. Ct. App. 1978)), affd sub nom. Standard Oil Co. v. Department of Energy, 596 F.2d 1029 (Emer. Ct. App. 1978).

147. See K. Davis, Administrative Law, Cases-Text-Problems 43-45 (6th ed. 1977);

B. SCHWARTZ, ADMINISTRATIVE LAW $\S 18$ (1976).

148. K. Davis, supra note $57, \S \S 2.00-4$ to -5 , at 52-53. 
found that the Civil Aeronautics Board's disregard of its past policy was reversible error. ${ }^{149}$ The court explained that while an "agency's view of what is in the public interest may change, ... an agency clianging its course inust supply a reasoned analysis indicating that prior policies and standards are being deliberately changed not casually ignored." 150 Ratlier than looking as it did to an uncertain "common law" of agency procedure as the source of the agency's "duty to define and apply its policies in a minimally responsible and evenhanded way," 151 the court could have looked to the congressional requirement that policy be formulated by the rulemaking process. This ruleinaking process contains procedural safeguards sufficient to imsure a rational, evenhanded application of new policy. ${ }^{152}$

The reasons for the courts' lesitation to exclude adjudication and to require rulemaking proceedings seein to arise from insufficient attention to the direction of Congress, from confusion created by Supreme Court decisions, and from misdirections caused by the substantive rule test. Anotlier and perliaps more substantial reason is the notion that an agency ought to have flexibility in its choice of procedure: an agency should be able "to clioose a procedural format it deems appropriate for the developinent of substantive policy." 153 But, as the Supreme Court recently acknowledged, ${ }^{154}$ this discretion is largely preserved by the ruleinaking process. The rulemaking process inerely requires that a form of public procedure be available so that interested parties lave soine opportunity to present their views and that standards affecting a segment of the public be codifled and published. Beyond these minimal requirements, an agency has substantial opportunities to fashion procedures. Policy may be developed "by oral or written communication and consultation; by specially summoned conferences; by advisory committees; or by liearimgs."15s If an agency determines that disputed factual matters need developinent beyond that of bare comment, then it may subject tliese matters to more intensive procedures; it nay, for ex-

149. Maine v. CAB, 520 F.2d 1240, 1245 (1st Cir. 1975).

150. Id. at 1245 .

151. Id. (quoting Distrigas of Massachusetts Corp. v. FPC, 517 F.2d 761, 765 (1st Cir. 1975)).

152. In particular, APA section 4(b) requires that, after standards are formulated by public procedure, these standards be published, along with "a general statement of their basis and purpose." 5 U.S.C. \& 553(c) (1976). This statement of the basis and purpose and the rule in itself should supply the "reasoned analysis" that the court in Maine v. CAB, 520 F.2d 1240 (1st Cir. 1975), deemed necessary.

153. Alianza Federal de Mercedes v. FCC, 539 F.2d 732, 738 (D.C. Cir. 1976).

154. See Vermont Yankee Nuclear Power Corp. v. National Resources Defense Council, Inc., 435 U.S. 519, 524 (1978).

155. ATT'y GENERAI's ReP. 103. 
ample, test these matters by a form of cross-examination. ${ }^{156}$

Apart from the merits of rulemaking, however, a greater principle bars agencies and reviewing courts from substituting adjudication for rulemaking. Congress, in delegating lawmaking authority to the agencies, established rulemaking as the exclusive process and cautioned the courts against subverting the integrity of the Administrative Procedure Act by "indirection."157 Rather, the courts are to enforce the Act and let practice expose its deficiencies. Then, according to Congress, "amendatory or supplementary legislation can supply any deficiency which experience discloses . . . "158 The greater primciple, then, is an orderly scheme of legislative control.

156. Id. 109.

157. S. REP. No. 752 at 29 . The Supreme Court recently cautioned reviewing courts "against engrafting their own notions of proper procedures upon agencies entrusted with substantive functions by Congress." Vermont Yankee Nuclear Power Corp. v. Natural Resources Defense Council, Inc., 435 U.S. 519,525 (1978). The Court further recognized the APA as "a legislative enactment which settled 'long-contimued and hard-fought contentions, and enacts a formula upon which opposing social and political forces have come to rest." "Id. at 523 (quoting Wong Yang Sun v. McGrath, 339 U.S. 33, 40 (1950)).

158. S. REP. No. 752 at 30 . In fact, Congress has exercised its supervisory functions. With respect to the adjudication or rulemaking problem, it has amended agency procedures to allow for special needs. The FTC, for example, occasionally is involved in substantial adjudication against an industry with a closely knit, coliesive membership. Congress, by the Federal Trade Commission Improvement Act of 1975, I5 U.S.C. $\$ \$ 2301-23$ I2 (1976), gave the FTC authority to issue an order-resulting from an adjudicative finding of an unfair or deceptive practice-that is binding on the entire industry. Federal Trade Commission Act, 15 U.S.C. $\$ 45(\mathrm{~m})(1)(B)(1976)$. 
